\title{
KARAKTERISTIK HABITAT, KEPADATAN DAN KOMPOSISI JENIS BIVALVIA DI ZONA INTERTIDAL PERAIRAN DESA WAWATU KECAMATAN MORAMO UTARA KABUPATEN KONAWE SELATAN
}

\section{Characteristics of Habitat, Density and Composition of the Bivalve Species in the Intertidal Zone Wawatu Village Waters, North Moramo District, South Konawe Regency}

\author{
${ }^{1}$ Tri Desmari, ${ }^{1}$ Muhammad Ramli, ${ }^{2}$ A. Ginong Pratikino \\ ${ }^{1}$ Progam Studi Ilmu Kelautan, ${ }^{2}$ Program Studi Oseanografi \\ Fakultas Perikanan dan Ilmu Kelautan, Uneversitas Halu Oleo. \\ Jl. HEA Mokodompit Kampus Hijau Bumi Tridharma Andunohu Kendari 93232 \\ 1*Email : Tridesmari03@gmail.com
}

\begin{abstract}
Abstrak
Zona Intertidal merupakan wilayah peralihan antara ekosistem laut dan ekosistem daratan (terestrial). Bivalvia merupakan salah satu kelompok organisme invertebrata yang banyak ditemukan dan hidup di daerah intertidal. Penelitian ini berujuan untuk mengetahui karakteristik habitat bivalvia, kepadatan dan komposisi jenis Bivalvia serta hubungan kepadatan dan komposisi jenis Bivalvia terhadap parameter perairan di Perairan Desa Wawatu Kecamatan Moramo Utara Kabupaten Konawe Selatan. Pengambilan data dilakukan pada Bulan Juni - Desember 2019 di Perairan Desa Wawatu, Kecamatan Moramo Utara. Metode pengambilan data bivalvi menggunakan metode Transek Kuadrat. Karakteristik substrat pasir dan lempung berpasir. Kepadatan bivalvia berkisar 2,8-4,3 ind $/ \mathrm{m}^{2}$. Kepadatan tertinggi bivalvi ditemukan daerah substrat lempung berpasir yang berasosiasi dengan padang lamun. Terdapat 7 jenis bivalvia yang ditemukan pada lokasi pengamatan. Komposisi jenis tertinggi bivalvia pada Tachycardium subrugosum dan Anadara granosa, sedangkan komposisi jenis terendah Pinna Muricata. Kepadatan jenis bivalvia memiliki hubungan korelasi positif yang sangat kuat dengan $\mathrm{pH}, \mathrm{BO}$ dan kedalaman.
\end{abstract}

Kata kunci: Bivalvia, Kepadatan, Komposisi Jenis, Intertidal, Wawatu

\section{Abstract}

The intertidal zone is a transitional area between sea and land (terrestrial). Bivalves are a group of invertebrate organisms that are found and live in intertidal areas. This study aims to determine the characteristics of the habitat of bivalves, density, and composition of the bivalves species as well as the relationship of density and composition of the bivalves species to water parameters in the waters of Wawatu Village, North Moramo District, South Konawe Regency. Data collection was carried out in June - December 2019 in Wawatu Village Waters, North Moramo District. The bivalve data collection method used the quadratic transect method. Characteristics of sand and sandy loam substrates. The bivalve density ranges from 2.8-4.3 ind./ $\mathrm{m} 2$. The highest density of bivalves was found in sandy clay substrate areas associated with seagrass beds. There are 7 species of bivalves found at the observation location. The highest species composition of bivalves was in Tachycardium subrugosum and Anadara granosa, while the lowest was Pinna muricata. Bivalve species density has a very strong positive correlation with $\mathrm{pH}, \mathrm{BO}$, and depth.

Keywords: Bivalve, Density, Composition of Species, Intertidal, Wawatu

\section{Pendahuluan}

Zona Intertidal merupakan wilayah peralihan antara ekosistem laut dan ekosistem daratan (terestrial). Sebagai wilayah peralihan, maka intertidal merupakan wilayah yang sangat menekan baik bagi organisme laut. Daerah ini merupakan daerah yang paling sempit namun memiliki keragaman dan kelimpahan organisme yang relatif lebih tinggi dibandingkan dengan habitat laut lainnya. Kelompok organisme intertidal umumnya terdiri dari lamun (sea grass), rumput laut (seaweed), komunitas karang (coral community), dan biota yang berasosiasi dengan karang dan lamun. Keragaman habitat akan menentukan komunitas dan biota yang berasosiasi dengan sistem ekologi di daerah pasang surut (Yulianda et all., 2013).

Bivalvia merupakan salah satu kelompok organisme invertebrata yang banyak ditemukan dan hidup di daerah intertidal. Hewan ini memiliki adaptasi khusus yang memungkinkan dapat bertahan hidup pada daerah yang memperoleh tekanan fisik dan kimia seperti terjadi pada daerah intertidal. Organisme ini juga memiliki adaptasi untuk bertahan terhadap arus dan gelombang. Namun, bivalvia tidak memiliki kemampuan untuk berpindah tempat secara 
cepat (motil), sehingga menjadi organisme yang sangat mudah untuk ditangkap (Susiana, 2011).

Bivalvia hidup di zona intertidal yang memiliki karakteristik habitat dengan bentuk sedimen yang sangat kompleks, yaitu sedimen yang berbentuk lumpur, berbatu dan berpasir. Biota ini sering dijumpai di daerah intertidal dan hidup dengan cara membenamkan diri, menggali dan meletakan diri pada substrat dengan mengunakan alat perekat pada karang dan batu (Resseck,1980).

Pesisir pantai Desa Wawatu merupakan daerah pasang surut yang memiliki area yang luas dengan variasi substrat pasir berlumpur serta terdapat banyak aktivitas masyarakat di sekitar pantai. Pada umumnya wilayah pantai banyak menyimpan keanekaragaman jenis biota. Keanekaragaman biota ini memerlukan perhatian khusus agar dapat lebih bermanfaat untuk dunia pendidikan dan perikanan. Salah satu biota yang dapat dijumpai di pesisir pantai Desa Wawatu adalah bivalvia, biota ini dimanfaatkan oleh masyarakat sebagai sumber untuk mencukupi kehidupan hidup bagi masyarakat setempat selain itu bivalvia juga sering dikonsumsi oleh masyarakat karena mengandung protein yang tinggi. Perairan Wawatu merupakan salah satu perairan yang berada di Kecamatan Moramo Utara, Kabupaten Konawe Selatan yang memilki jenis bivalvia yang tersebar di perairan.

Tujuan dari penelitian ini adalah mengetahui karakteristik habitat bivalvia di Perairan Desa Wawatu Kecamatan Moramo Utara Kabupaten Konawe Selatan, mengetahui kepadatan dan komposisi jenis Bivalvia di Periran Desa Wawatu Kecamatan Moramo Utara Kabupaten Konawe Selatan, mengetahui hubungan kepadatan dan komposisi jenis Bivalvia terhadap parameter perairan di Periran Desa Wawatu Kecamatan Moramo Utara Kabupaten Konawe Selatan.

\section{Bahan dan Metode}

Penelitian ini dilaksanakan pada Bulan Juni-Desember 2019, yang meliputi pengambilan data dan pengolahan data penelitian. Lokasi pengambilan sampel dan data penelitian di Perairan Desa Wawatu, Kecamatan Moramo Utara, Kabupaten Konawe Selatan, Provinsi Sulawesi Tenggara. Analisis substrat di Laboratorium Fakuktas Teknik Universitas Halu Oleo.

Survei pendahuluan dilakukan untuk mengetahui kondisi lokasi penelitian secara menyeluruh dan untuk menentukan titik stasiun pengambilan sampel dan penentuan metode penelitian di lakukan di desa wawatu dan di survey awal di dapatkan berbagai jenis bivalvia.

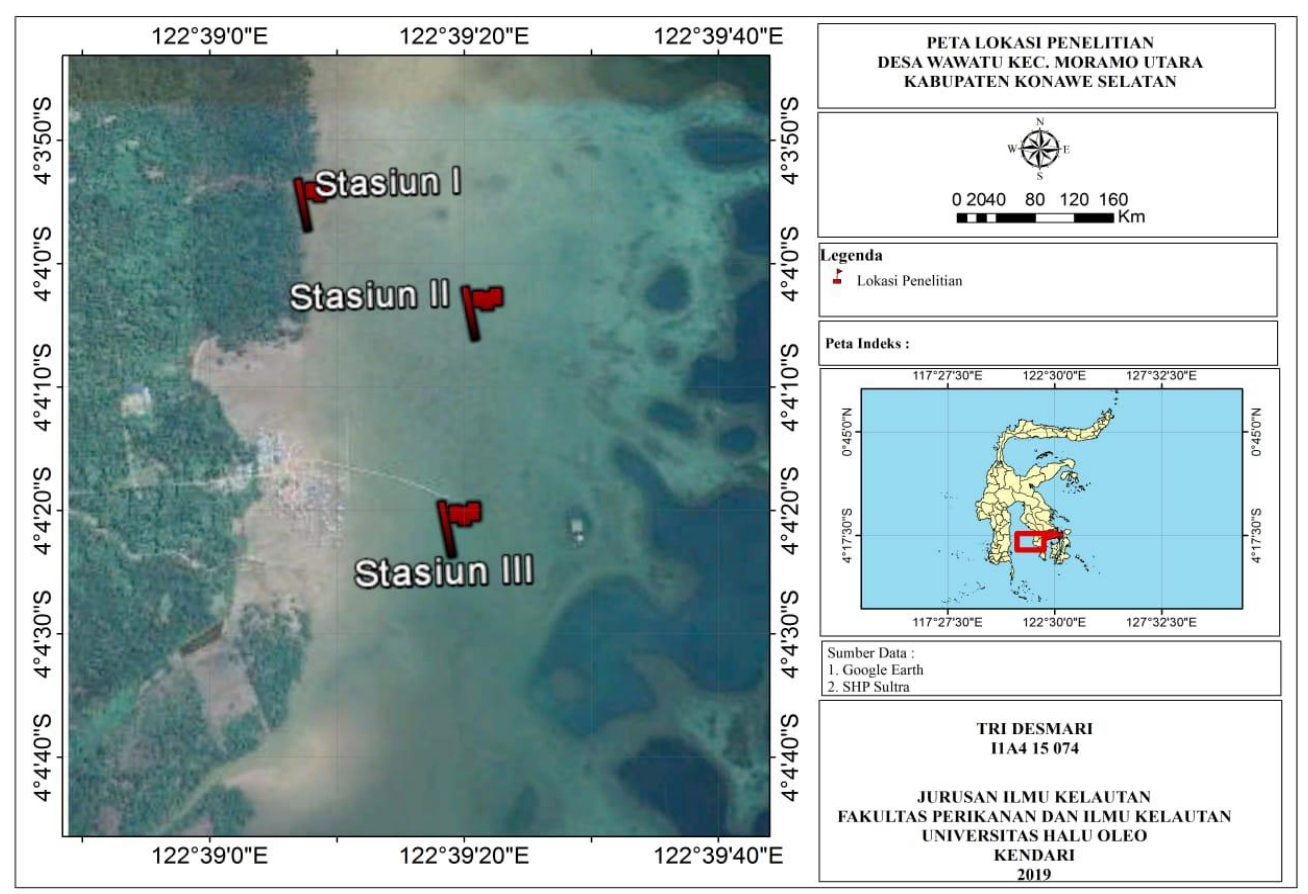

Gambar 1. Peta lokasi penelitian di Perairan Desa Wawatu, Moramo Utara, Konawe Selatan 
Tabel 1. Alat dan Bahan Penelitian Berserta Kegunaannya

\begin{tabular}{|c|c|c|c|c|}
\hline Parameter & Satuan & Alat/Metode & Kegunaan & Keterangan \\
\hline $\begin{array}{l}\text { Fisika } \\
\text { - Suhu Perairan } \\
\text { - Kedalaman } \\
\text { Perairan } \\
\text { - Kecepatan } \\
\text { arus } \\
\text { - Menyimpan } \\
\text { sampel } \\
\end{array}$ & $\begin{array}{l}{ }^{\circ} \mathrm{C} \\
\mathrm{cm}\end{array}$ & $\begin{array}{l}\text { Thermometer } \\
\text { Patok berskala } \\
\text { Layangan arus } \\
\text { Plastik sampel }\end{array}$ & $\begin{array}{l}\text { Mengukur suhu perairan } \\
\text { Mengukur kedalaman } \\
\text { Mengukur kepatan arus } \\
\text { Menyimpan sampel }\end{array}$ & $\begin{array}{l}\text { Lapangan } \\
\text { Lapangan } \\
\text { Lapangan } \\
\text { Lapangan }\end{array}$ \\
\hline $\begin{array}{l}\text { Kimia } \\
\text { - Salinitas } \\
-\mathrm{pH}\end{array}$ & $\begin{array}{c}\%_{0} \\
-\end{array}$ & $\begin{array}{l}\text { Handrefraktometer } \\
\text { pH indikator }\end{array}$ & $\begin{array}{l}\text { Mengukur salinitas } \\
\text { Mengukur pH Perairan } \\
\text { Mengukur substrat }\end{array}$ & $\begin{array}{l}\text { Lapangan } \\
\text { Lapangan } \\
\text { Lapangan }\end{array}$ \\
\hline $\begin{array}{l}\text { - Substrat } \\
\text { - BO }\end{array}$ & $\begin{array}{l}\mathrm{ml} / 1 \\
\mathrm{ml} / 1\end{array}$ & $\begin{array}{l}\text { Pipa paralon } \\
\text { Pipa paralon }\end{array}$ & Mengukur BO & Lapangan \\
\hline $\begin{array}{l}\text { Biologi } \\
\text { - Bivalvia }\end{array}$ & Ind & $\begin{array}{l}\text { Transek kuadrat } \\
\text { 1x1 dan Skop }\end{array}$ & Objek pengamatan & Lapangan \\
\hline
\end{tabular}

Setelah dilakukan survei pendahuluan, selanjutnya dilakukan penentuan titik stasiun penelitian dengan menggunakan GPS. Titik stasiun pengambilan data yang akan diamati sebanyak tiga stasiun berdasarkan keberadaan bivalvia. Stasiun I, terletak dibagian Utara Perairan Desa Wawatu, daerah ini berada pada daerah manggrove yang memiliki kerapatan mangrove yang cukup rapat. Stasiun I berada pada koordinat titik kordinat 404'10,79" S 122039'10,92" BT. Stasiun II, Terletak di bagian Utara Perairan Desa Wawatu, daerah ini berada pada daerah lamun yang cukup rapat, terletak dengan titik kordinat 404'12,51" S 122039'10,79” BT. Stasiun III, terletak di bagian Selatan Perairan Desa Wawatu, daerah ini berdekatan dengan aliran sungai Desa Wawatu dengan titik kordinat 404'14,26" S 122039'11,79” BT.

Pengambilan sampel bivalvia dilakukan pada setiap stasiun penelitian, diperoleh dengan menggunakan metode transek garis (Fachrul, 2007). Transek garis yang dibentangkan secara tegak lurus pantai. Dengan jarak $100 \mathrm{~m}$, sesuai dengan keberadaan bivalvia. Masing-masing garis transek diletakan transek kuadrat $(1 \times 1$ m) dengan jarak ukur kuadran $10 \mathrm{~m}$ dengan cara zig-zag atau (selang seling). Pengambilan data di setiap stasiunnya dilakukan sebanyak 3 kali pengulangan.

Sampel bivalvia yang terdapat di dalam transek dihitung jumlah perjenisnya kemudian didokumentasikan dengan menggunakan kamera digital dan bivalvia yang tidak dapat diidentifikasi secara langsung di masukan ke dalam plastik sampel dan diidentifikasi sesuai dengan panduan (Gambar 3).

Parameter lingkungan diukur secara (in situ) untuk mengetahui kondisi perairan yang ada di lokasi penelitian. Pengukuran parameter lingkungan dilakukan pada saat air pasang disetiap stasiun. Parameter perairan yang diambil berupa salinitas, suhu, BO, kedalaman, dan $\mathrm{pH}$ substrat.

Data suhu diperoleh dengan menggunakan alat bantu thermometer. Thermometer yang bagian atasnya telah diikat dengan tali dimasukkan ke dalam kolom perairan, diamkan selama \pm 3 menit, kemudian termometer ditarik ke bagian permukaan, namun bagian bawah termometer masih berada dalam kolom perairan guna mengurangi galat data. Selanjutnya, dilihat cairan raksa yang menunjukkan angka data suhu.

Informasi kecepatan arus diperlukan untuk mengetahui arah dan besarnya massa air yang mengalir serta mengetahui penyebaran, sedimen atau bahan lainnya. Pengukuran kecepatan arus dilakukan dengan menggunakan layangan arus yang dilengkapi dengan tali berskala (panjang tali 5 meter). Layangan arus dilepaskan ke perairan dan dibiarkan terapung dan dibawa arus hingga tali pengulur lurus horizontal. Waktu awal pelepasan layanglayang arus hingga waktu akhir tali lurus horizontal dicatat dengan menggunakan stopwatch. Tiap-tiap pengukuran dilakukan 3 kali pengulangan 


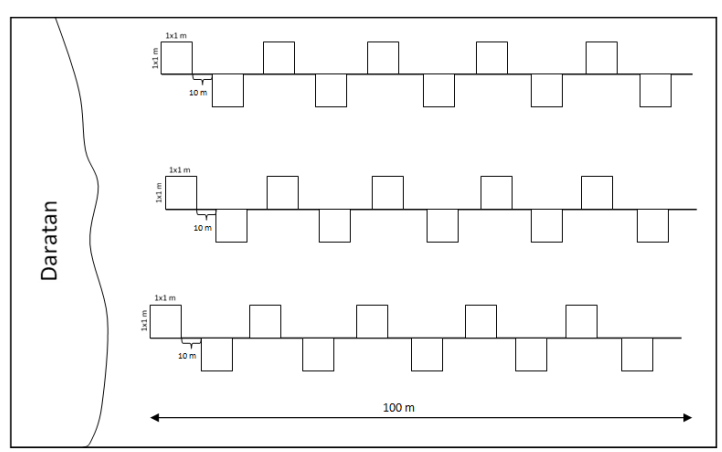

Gambar 3. Sketsa pengambilan sampel bivalvia

Data salinitas diperoleh dengan menggunakan alat Handrefraktometer. Sebelum digunakan, Handrefraktometer dapat dikalibrasi terlebih dahulu dengan cara ditetesi air akuades, sehingga nilai awal salinitas di angka nol, setelah itu Handrefraktometer siap untuk digunakan. Ambil air dan teteskan sebanyak 1-2 tetes pada Handrefraktometer, kemudian Handrefraktometer diarahkan ke sumber cahaya matahari, lalu dilihat tepat pada kisaran nilai salinitas.

Kertas indikator $\mathrm{pH}$ merupakan alat yang digunakan untuk mengambil data $\mathrm{pH}$. Kertas indikator $\mathrm{pH}$ dicelupkan ke dalam perairan, diamkan \pm 3 menit, lalu angkat kertas indikator $\mathrm{pH}$ dari dalam perairan. Kemudian, dicocokkan dengan $\mathrm{pH}$ indikator untuk mengetahui kisaran nilai $\mathrm{pH}$ yang diperoleh dari hasil pengukuran.

Kedalaman perairan diukur dengan menggunakan patok berskala kemudian patok diturunkan ke dalam perairan hingga menyentuh dasar perairan. Kemudian, baca kedalaman perairan yang diperoleh sesuai dengan skala yang dibuat dan dicatat hasilnya.

Pengambilan substrat menggunakan pipa paralon $30 \mathrm{~cm}$ dengan cara memasukkan pipa paralon kedalam plot penelitian, lalu mengambil substrat tersebut dan memasukkan kedalam kantong plastik yang telah diberi kode. Lalu dikeringkan, setelah itu sampel substrat dibawa ke Laboratorium Fakultas Teknik, Universitas Halu Oleo untuk diuji jenis substratnya.

Pengambilan sampel bahan organik dilakukan dengan menggunakan core yang terbuat dari pipa paralon dengan ukuran diameter 2 inch dengan panjang $20 \mathrm{~cm}$. Pengambilan sampel sedimen dilakukan dengan menancapkan core pada sedimen hingga tenggelam lalu mengangkat kembali core tersebut, kemudian memasukkan ke dalam kantong sampel sesuai dengan kode sampel setiap plot yang telah dibuat, setelah itu menyimpan kedalam cool box yang berisi es batu. Fungsi es batu sebagai pendingin agar tidak terjadi penguraian oleh bakteri. Sampel dibawa kelaboratorium untuk dianalisis.

Kepadatan bivalvia dihitung dengan menggunakan persamaan menurut Odum (1996):

$$
D i=\frac{n i}{A}
$$

Keterangan :

$\mathrm{Di}=$ Kepadatan individu (ind $\left./ \mathrm{m}^{2}\right)$

$\mathrm{ni}=$ Jumlah total individu

$\mathrm{A}=$ Luas daerah yang di sampling $\left(\mathrm{m}^{2}\right)$

Komposisi jenis bivalvia dihitung menggunakan persamaan menurut Odum (1996) sebagai berikut:

$P i=\frac{n i}{N} x 100$

Keterangan :

$\mathrm{Pi}=$ Peresentase tiap jenis $(\%)$,

$\mathrm{ni}=$ Jumlah individu spesies ke-i,

$\mathrm{N}=$ Jumlah total individu

Pengolahan hubungan persentase

karakteristik habitat dengan kepadatan dan komposisi jenis bivalvia menggunakan rumus Sugiono (2007) sebagai berikut:

$r=\frac{N \sum X Y-\left(\sum X\right)\left(\sum Y\right)}{\sqrt{N \sum X^{2}}-\left(\sum X\right)^{2}\left(N \sum Y^{2}-\left(\Sigma Y^{2}\right)\right)}$

Keterangan :

$\mathrm{r}=$ Koefisien korelasi

$\mathrm{X}=$ Variabel yang diukur

$\mathrm{N}=$ Jumlah total sampel

$\mathrm{Y}=$ Variabel yang diukur

Tabel 2. Kriteria Koefisien Korelasi

\begin{tabular}{cc}
\hline $\begin{array}{c}\text { Interval Koefisien } \\
\text { Korelasi }\end{array}$ & Tingkat Hubungan \\
\hline $0,00-0,199$ & Sangat rendah \\
$0,20-0,399$ & Rendah \\
$0,40-0,599$ & Sedang \\
$0,60-0,799$ & Kuat \\
$0,80-1,00$ & Sangat kuat \\
\hline
\end{tabular}

\section{Hasil dan Pembahasan}

Zona intertidal (pasang surut) merupakan daerah tersempit dari semua daerah yang terdapat di samudera dunia, walaupun luas daerah ini sangat terbatas, tetapi memiliki variasi faktor lingkungan yang terbesar dibandingkan dengan daerah lautan lainnya. Daerah ini memiliki zona intertidal (panjang $\pm 1 \mathrm{~km}$ dan luas $\pm 2,5 \mathrm{~km}$ ) ini juga merupakan habitat baigi organisme laut salah 
satunya adalah bivalvia yang ditemukan hidup di dalam substrat dasar perairan dan terseber di seluruh perairan intertidal. Hal ini sesuai dengan pernyataan Wally (2011), yang menyatakan bahwa pada daerah intertidal organisme bentik yang hidup lebih banyak dari jenis organisme yang menetap pada dasar substrat seperti golongan kerang, karena jenis substrat mempengaruhi cara adaptasi, pola migrasi, berkembang biak, mencari makan dan mekanisme pertahanan.

Keberadaan bivalvia pada lokasi penelitian didukung oleh kondisi Substrat dasar perairan, dimana bivalvia ditemukan pada daerah yang cenderung memiliki tipe Substrat lumpur, kondisi ini memungkinkan bivalvia untuk hidup dan tumbuh berkembang, karena bivalvia memiliki kebiasaan membenamkan diri di Substrat dasar perairan sehingga tipe substrat yang cenderung berlumpur lebih disukai oleh bivalvi. Pada lokasi penelitian dimana pada stasiun II dan III dengan tipe substrat lempung berpasir banyak ditemukan bivalvia yang membenamkan diri di Substrat sedangkan pada stasiun I dengan tipe substrat pasir, keberadaan bivalvia yang ditemukan cenderung sedikit. Hal ini sesuai dengan pernyataan Odum, (1994) menyatakan bahwa kehidupan bivalvia sering ada di perairan yang dipermukaannya terdapat substrat pasir atau lumpur. Bivalvia biasanya hidup dengan membenamkan dirinya di pasir, lumpur atau permukaaan Substrat.

Tabel 3. Kepadatan bivalvia pada Lokasi Penelitian

\begin{tabular}{|c|c|c|}
\hline Stasiun & $\begin{array}{c}\text { Jumlah } \\
\text { individu }\end{array}$ & $\begin{array}{c}\text { Kepadatan } \\
\left(\text { Individu/ } / \mathrm{m}^{2}\right)\end{array}$ \\
\hline I & 84 & 2,8 \\
\hline II & 129 & 4,3 \\
\hline III & 114 & 3,8 \\
\hline
\end{tabular}

Dari hasil penelitian yang dilakukan di Perairan Desa Wawatu, kepadatan tertinggi pada stasiun II yakni dengan nilai kepadatan 4,3 Ind $/ \mathrm{m}^{2}$ sedangkan kepadatan terendah berada pada stasiun I dengan nilai kepadatan 2,8 Ind $/ \mathrm{m}^{2}$

Berdasarkan hasil penelitian yang dilakukan di Perairan Desa Wawatu diperoleh nilai kepadatan bivalvia pada masing-masing stasiun beragam, kepadatan tertinggi berada pada stasiun II yakni dengan nilai kepadatan 4,3 Ind $/ \mathrm{m}^{2}$ dan kepadatan terendah pada stasiun I dengan nilai kepadatan 2,8 Ind $/ \mathrm{m}^{2}$ (Tabel 3 dan 4). Tingginya nilai kepadatan bivalvia pada stasiun II karena pada stasiun ini berada pada kawasan padang lamun, dimana padang lamun merupakan ekosistem laut yang penting dan mampu menyediakan makanan, habitat, dan daerah merupakan asuhan bagi bivalvi. Hal ini sesuai sengan pernyataan Hermala et al. (2015). yang menyatakan bahwa asosiasi bivalvia dan lamun mempunyai keterkaitan yang kuat dalam siklus makanan. Serasah pada lamun akan mengendap didasar perairan yang kemudian diuraikan oleh mikroorganisme yang menjadi makanan bivalvia.

Komposisi jenis bivalvia pada lokasi penelitian ditemukan 7 jenis bivalvia yang tersebar disemua titik stasiun. Spesies yang paling sering ditemukan pada titik sampling yaitu spesies Tachycardium subrugosum, Anadara granosa sedangkan spesies yang paling jarang ditemukan titik sampling yaitu spesies Pinna muricata. Tingginya nilai komposisi jenis Tachycardium subrugosum, Anadara granosa pada lokasi penelitian karena jenis ini senang mendiami Substrat lempung berpasir dan ditemukan membenamkan diri di dalam substrat. Selain itu jenis Tachycardium subrugosum, Anadara granosa banyak ditemukan di daerah lamun, bivalvia memanfaatkan lamun sebagai habitat karena daerah lamun diketaui kaya akan bahan organik yang dimanfaatkan oleh bivalvia sebagai bahan makanan. Pada lokasi penelitian dimana pada stasiun II yaitu pada daerah lamun ditemukan bahan oraganik yang cenderung tinggi dan banyak ditemukan bivalvia jenis Tachycardium subrugosum, Anadara granosa. Hal ini sesuai dengan pernyataan Hermawati et al., (2017) menyatakan bahwa bivalvia menjadikan kawasan lamun sebagai habitat untuk tempat berlindung, daerah asuhan dan mencari makan. Intan (2012), yang menyatakan bahwa jenis Anadara granosa hidup membenamkan diri di dalam lumpur atau lumpur berpasir di daerah litoral. Anadara granosa termasuk hewan benthos yang mendiami wilayah pasang surut (zona intertidal). Menurut Setyono (2006), menyatakan bahwa Tachycardium subrugosom ini gemar memendamkan dirinya kedalam pasir atau lumpur. 
Tabel 4. Komposisi jenis bivalvia pada Lokasi Penelitian

\begin{tabular}{clccc}
\hline \multirow{2}{*}{ No } & \multirow{2}{*}{ Jenis Bivalvia } & \multicolumn{3}{c}{ Komposisi Jenis (\%) } \\
\cline { 3 - 5 } & & Stasiun I & Stasiun II & Stasiun III \\
\hline 1 & Tachycardium subrugosum & 50 & - & - \\
2 & Barabtia decussata & 25 & - & 42,10 \\
3 & Donax farba & 17,85 & 18,60 & 7,89 \\
4 & Pinna muricata & 7,14 & - & - \\
5 & Anadara granosa & - & 41,86 & 50 \\
6 & Circe tumefacta & - & 23,25 & - \\
7 & Gafrarium tumidum & - & 16,27 & - \\
\hline \multicolumn{2}{c}{ Jumlah } & 99,99 & 99,98 & 99,99 \\
\hline
\end{tabular}

Tabel 5. Parameter Lingkungan pada Lokasi Penelitian

\begin{tabular}{clccc}
\hline \multirow{2}{*}{ No } & \multicolumn{1}{c}{$\begin{array}{c}\text { Parameter } \\
\text { Lingkungan }\end{array}$} & I & II & III \\
\cline { 3 - 5 } & & 28 & 29 & 28 \\
\hline 1 & Suhu $\left.{ }^{(0} \mathrm{C}\right)$ & 0,07 & 0,07 & 0,06 \\
2 & Kecepatan arus $(\mathrm{m} / \mathrm{s})$ & 29 & 30 & 28 \\
3 & Salinitas $\% 00$ & 6 & 7 & 7 \\
4 & $\mathrm{pH}$ & 0,989 & 3,164 & 1,615 \\
5 & BO $(\mathrm{mg} / \mathrm{L})$ & Pasir & Lempung & Lempung \\
6 & Tipe substrat $(\mathrm{mg} / \mathrm{L})$ & 120 & berpasir & berpasir \\
7 & Kedalaman $(\mathrm{cm})$ & & 132 & 128 \\
\hline
\end{tabular}

Tabel 6. Korelasi Kepadatan Bivalvia Terhadap Parameter Perairan.

\begin{tabular}{ccccccc}
\hline \multirow{2}{*}{ Kepadatan } & \multicolumn{5}{c}{ Korelasi } \\
\cline { 2 - 7 } & suhu & kec. Arus & salinitas & $\mathrm{pH}$ & Kedalaman & $\mathrm{BO}$ \\
\hline 5,6 & 0,75 & 0,45 & 0,32 & 0,94 & 1 & 0,90 \\
8,6 & 0,75 & & & & & \\
7,6 & & &
\end{tabular}

Tabel 7. Korelasi Komposisi Jenis Bivalvia Terhadap Parameter Perairan.

\begin{tabular}{lcccccccc}
\hline $\begin{array}{l}\text { Jenis } \\
\text { Bivalvia }\end{array}$ & Stasiun & $\begin{array}{c}\text { Komposisi } \\
\text { Jenis }\end{array}$ & Suhu & $\begin{array}{c}\text { Kec. } \\
\text { Arus }\end{array}$ & Salinitas & $\mathrm{pH}$ & Kedalaman & BO \\
\hline Anadara & II & 41,86 & 29 & 0,7 & 30 & 7 & 132 & 3,164 \\
granosa & III & 50 & 28 & 0,6 & 28 & 7 & 128 & 1,615 \\
\hline & Korelasi & & -1 & -1 & -1 & $\infty$ & -1 & -1 \\
\hline Barabtia & I & 25 & 28 & 0,7 & 29 & 6 & 120 & 0,989 \\
decussata & III & 42,10 & 28 & 0,6 & 28 & 7 & 128 & 1,615 \\
\hline & korelasi & & $\infty$ & -1 & -1 & 1 & 1 & 1 \\
\hline
\end{tabular}

Berdasarkan hasil analisis komposisi jenis bivalvia Anadara granosa berbanding terbalik dengan parameter fisik kimia perairan (suhu, kecepatan arus, salinitas, $\mathrm{pH}$, kedalaman, BO) dan komposisi jenis bivalvia Barabtia decussata memiliki hubungan korelasi sangat kuat pada parameter perairan $\mathrm{pH}$, kedalaman dan $\mathrm{BO}$ sedangkan suhu, kecepatan arus dan salinitas berbanding terbalik.

Kepadatan dan komposisi jenis bivalvia juga disebabkan oleh faktor kualitas perairan, perairan yang baik akan menunjang pertumbuhan dan keberlangsungan hidup bivalvia seperti suhu, $\mathrm{pH}$, kecepatan arus dan salinitas. Hasil pengukuran suhu pada 
perairan tersebut berkisar antara $28-39{ }^{\circ} \mathrm{C}$, Kecepatan arus yang diperoleh berkisar 0,060,07 m/s, pH 6-7 dan salinitas 28-30\% \% Hal tersebut menunjukan bahwa suhu, $\mathrm{pH}$, salinitas, dan kecepatan arus di perairan tersebut masih dapat menunjang pertumbuhan dan keberlangsungan hidup bivalvia. Hal ini sesuai dengan pernyataan Nur (2012) yang menyatakan, Suhu yang sesuai untuk bivalvia berkisar antara $28^{\circ} \mathrm{C}-31^{\circ} \mathrm{C}, \mathrm{pH}$ yang baik untuk mendukung kehidupan organisme perairan berkisar antara 5,0-8,0, Bahan organik yang terlarut dalam perairan selain merupakan sumber nutrisi juga merupakan salah satu faktor yang mempengaruhi pertumbuhan, kehadiran dan kepadatan hewan bentos.

Berdasarkan hasil analisis hubungan korelasi kepadatan dengan parameter perairan diperoleh nilai koefisien positif dimana suhu memiliki nilai koefisien 0,75 (kuat), kecepatan arus 0,45 (sedang), salinitas 0,32 (rendah) dan $\mathrm{pH}, \mathrm{BO}$ dan kedalaman memiliki nilai koefisien yang sangat kuat dengan kisaran nilai 0,90 sampai 1 . Hal ini memberikan gambaran bahwa terhadap hubungan signifikan antara variable bebas yakni parameter perairan dengan variable terikat yakni kepadatan bivalvia. Kepadatan bivalvia tertinggi berada pada stasiun II, pada stasiun ini kondisi perairan cenderung subur dengan suhu $29{ }^{\circ} \mathrm{C}$, kecepatan arus 0,075 $\mathrm{m} / \mathrm{s}$, salinitas $30 \%, \mathrm{pH} \mathrm{7,} \mathrm{BO} \mathrm{3,164} \mathrm{mg/l,}$ tipe substrat lempung berpasir, dan untuk kedalaman $132 \mathrm{~cm}$, keadaan ini menunjang keberlangsungan hidup bivalvia dan memanfaatkan kondisi tersebut untuk keberlangsungan hidup bivalvia. Menurut Suwondo (2012), kisaran pH air yang mendukung kehidupan bivalvia adalah berkisar 6-9. Nasution (2009), suhu optimal bagi kehidupan kerang Anadara adalah sekitar 25-32 ${ }^{\circ} \mathrm{C}$. Hal Yunitawati et al. (2012), bahwa jenis dari kelas bivalvia dapat tumbuh dan berkembang dengan baik dengan tipe substrat berlumpur dengan bahan organik tinggi sebagai pakan. Iswanti (2012) menambahkan bahwa kehadiran spesies dalam suatu komunitas zoobentos disukung oleh kandungan organik yang tinggi dan tipe Substrat. Menurut Rizal et al. (2013), arus merupakan faktor pembatas karena dapat mempengaruhi kehidupan bivalvia dimana arus yang kuat akan menghempaskan organisme, sehingga hanya jenis-jenis tertentu yang mampu bertahan. Namun, arus dapat pula mendukung kehidupan bivalvia, karena selalu membutuhkan arus untuk memperoleh makanan.

\section{Kesimpulan}

Berdasarkan hasil penelitian yang telah dilakukan di perairan Perairan Desa Wawatu, Kec. Moramo Utara dapat disimpulkan, sebagai berikut :

1. Keberadaan bivalvia paling banyak ditemukan pada daerah substrat lempung berpasir karena memiliki kebiasaan membenamkan dirinya, selaintu $\mathrm{pH}$, suhu dan BO memiliki hubungan yang kuat dimana nilai $\mathrm{pH} 7$, suhu $28-29{ }^{\circ} \mathrm{C}$ dan $\mathrm{BO}$ $1,615 \mathrm{mg} / \mathrm{L}$ sampai dengan $3,164 \mathrm{mg} / \mathrm{L}$.

2. Kepadatan bivalvia berkisar dari 2,8 $\mathrm{ind} / \mathrm{m}^{2}$ sampai $4,3 \mathrm{ind} / \mathrm{m}^{2}$ dengan komposisi jenis tertinggi yaitu Tachycardium subrugosum, Barabtia decussata dan Anadara granosa.

3. Kepadatan bivalvia memiliki hubungan korelasi positif yang kuatdengan suhu dan hubungan yang sangat kuat dengan $\mathrm{pH}$, BO dan kedalaman, untuk komposisi jenis Barabtia decussata memiliki hubungan sagat kuat dengan $\mathrm{pH}, \mathrm{BO}$ dan kedalaman sedangkan para meter yang lain berbanding terbalik, begitu pula dengan komposisi jenis Anadara granosa berbanding terbalik parameter perairan.

\section{Daftar Pustaka}

Hermala, A., Zulfikar dan T. S. I. Raza. 2015. Hubungan Kerapatan Lamun dengan Kelimpahan Bivalvia di Pesisir Pantai Dolpin Desa Teluk Bakau Kabupaten Bintan. Universitas Maritim Raja Ali Hajli, Kepulauan Riau.

Hermawati, P., Barus, T. A., Wahyuningsih, H. 2007. Keanekaragaman Makrozoobenthos dan Hubungannya dengan Tutupan Padang Lamun (Seagrass) di Perairan Mandailing Natal Sumatra Utara. Jurnal Biosains. $3(2): 66-72$.

Intan, Afrizal, T., Irvina, N., 2012. Kerang Darah (Anadara granosa) Abudance in Coastal Water of Tanjungbalai Asahan North Sumatera.

Iswanti. 2012. Distribusi dan Keanekaragaman Jenis Makrozoobenthos di Sungai Damar Desa 
Weleri Kabupaten Kendal. Journal of Life Science 1(2): 86-93.

Nasution, S. 2009. Biomassa Kerang Anadara granosa pada Perairan Pantai Kabupaten Indragiri Hilir. Jurnal Natur Indonesia, 12 (1): 61-66.

Nur, A. I. S. 2012. Distribusi dan Keanekaragaman Bivalvia di Perairan Puntondo Kabupaten Takalar. Skripsi. Jurusan Biologi pada Fakultas Sains dan Teknologi, Universitas Islam Negeri Alauddin Makassar.

Odum, E. P. 1994. Dasar-dasar Ekologi. Gadjah Mada University Press, Yogyakarta (diterjemahkan oleh $\mathrm{T}$. Sumingan dan B. Srigandono). 697 hlm.

Odum, E.P. 1996. Dasar-dasar Ekologi. Edisi ketiga. Gaja Mada Universitas Press. Jogjakarta.

Reseck Jr., Jhon. 1980. Marine biology. 2nd. Edit. Pretince-Hall Inc. New Jersey. Fauna of Australia. Vol.5. CSIRO Publising. Melbourne.

Rizal., Emiyarti dan Abdullah. 2013. Pola Distribusi dan Kepadatan Kijing Taiwan (Anadonta woodiana) di Sungai Aworeka Kabupaten Konawe. Jurnal Mina Laut Indonesia, 2 (6): 142-153.

Romimohtarto, K dan Juwana, S. 2009. Biolo gi Laut Ilmu Pengetahuan TentangBio ta Laut. Jakarta: Djambatan.

Setyono, D. E. D. 2006. Karakteristik Biologi dan Produk Kekerangan Laut. Jurnal Oseana 31, (1) : 1-7.

Sugiyono. 2007. Metode penelitian administasi. Bandung : Alfabeta.

Susiana. 2011. Diversitas dan kerapatan manggrove, Gastropoda dan Bivalvia di estuaria perancak Bali (skripsi) Fakultas Matematika dan Ilmu Pengetahuan Alam universitas Hasanudin, Makassar.

Suwondo., E. Febrita dan N. Siregar. 2012. Kepadatan dan Distribusi Bivalvia pada Mangrove di Pantai Cermin Kabupaten Serdang Bedagai Provinsi Sumatra Utara. Jurnal Biogenesis, 9 (1): 45-50.

Wally, D. A. 2011. Adaptasi Organisme Bentik di Zona Intertidal. Universitas Darussalam Ambon. Bimafika. Vol. 3 : 244-249.

Yulianda, F., Salamuddin, M.Y., Windy, P. 2013. Zonasi Dan Kepadatan Komunitas Intertidal Di Daerah Pasang
Surut, Pesisir Batuhijau, Sumbawa. Jurnal Ilmu dan Teknologi Kelautan Tropis, Vol. (5) 2 : 409-416.

Yunitawati., Sunarto dan Z. Hasan. 2012. Hubungan antara Karakteristik Substrat dengan Struktur Komunitas Makrozoobenthos di Sungai Cantigi, Kabupaten Indramayu. Jurnal Perikanan dan Kelautan, 3(3): 221227. 